\title{
HUBUNGAN ANTARA KECERDASAN EMOSI DENGAN PENERIMAAN TEMAN SEBAYA PADA REMAJA DI MASA PANDEMI COVID-19
}

\author{
${ }^{1}$ Elvida Yusri, ${ }^{2}$ Yulia Herawaty \\ 1, 2 Fakultas Psikologi, Universitas Islam Riau, Indonesia. \\ ${ }^{1}$ Corresponding Author: elvidayusri70@gmail.com
}

\begin{abstract}
The Covid-19 pandemic has had so many impacts on human life, including the development of adolescents. Adolescents during the Covid-19 pandemic have various problems they must face. The lack of peer acceptance in adolescents during the pandemic causes bored, loneliness, stress, and has an impact on declining academic achievement. One of the factors assumed to be related to peer acceptance is emotional intelligence. The purpose of this study was to determine the relationship between emotional intelligence and peer acceptance in adolescents during the Covid-19 pandemic. The population in this study were adolescents aged 12-19 years with a sample of 100 people obtained by incidental sampling technique. The data collection method uses a modified emotional intelligence scale from Putri (2016) and a peer acceptance scale by Rahmana (2012). Data were analyzed using Spearman's Rank correlation where the results showed a correlation value of 0.547 with a significance value of $0.000(p<0.05)$. It can be concluded that there is a positive and significant relationship between emotional intelligence and peer acceptance in adolescents during the Covid-19 pandemic, meaning that the higher the emotional intelligence, the higher the peer acceptance, on the contrary, the lower the emotional intelligence, the lower the peer acceptance.
\end{abstract}

Keywords: Emotional Intelligence, Peer Acceptance, Adolescents

\begin{abstract}
ABSTRAK
Pandemi Covid-19 memberikan begitu banyak dampak terhadap kehidupan manusia termasuk pada perkembangan remaja. Remaja di masa pandemi Covid-19 memiliki berbagai permasalahan yang harus mereka hadapi. Kurangnya penerimaan teman sebaya pada remaja di masa pandemi menimbulkan rasa bosan, kesepian, stress, dan berdampak pada prestasi akademik yang menurun. Salah satu faktor yang diasumsikan berhubungan dengan penerimaan teman sebaya adalah kecerdasan emosi. Tujuan penelitian ini adalah untuk mengetahui hubungan antara kecerdasan emosi dengan penerimaan teman sebaya pada remaja di masa pandemi Covid-19. Populasi pada penelitian ini adalah remaja usia 12-19 tahun dengan sampel sebanyak 100 orang yang diperoleh dengan teknik sampling insidental. Metode pengumpulan data menggunakan skala kecerdasan emosi yang telah dimodifikasi dari Putri (2016) dan skala penerimaan teman sebaya oleh Rahmana (2012). Data dianalisis menggunakan korelasi Spearman's Rank di mana hasilnya menunjukkan nilai korelasi sebesar 0,547 dengan nilai signifikansi 0,000 $(p<0,05)$. Dapat disimpulkan bahwa terdapat hubungan yang positif dan signifikan antara kecerdasan emosi dengan penerimaan teman sebaya pada remaja di masa pandemi Covid-19, artinya semakin tinggi kecerdasan emosi maka semakin tinggi penerimaan teman sebaya, sebaliknya semakin rendah kecerdasan emosi semakin rendah pula penerimaan teman sebaya.
\end{abstract}

Kata Kunci: Kecerdasan Emosi, Penerimaan Teman Sebaya, Remaja 


\section{PENDAHULUAN}

Pandemi Covid-19 kini telah memasuki tahun kedua sejak pemerintah mengumumkan bahwa virus ini telah masuk ke Indonesia. Covid-19 adalah virus yang sangat berbahaya yang penularannya dapat terjadi dengan mudah dari satu individu terhadap individu yang lain dan dapat menyebabkan kematian. Sejak dunia menghadapi wabah ini termasuk di Indonesia, berbagai sektor mengalami kelumpuhan baik dari segi ekonomi, sosial, pariwisata, hingga pendidikan.

Melakukan aktifitas selama masa pandemi merupakan sebuah tantangan dan hal baru yang harus dihadapi masyarakat termasuk peserta didik dalam sektor pendidikan. Menurut Hall (dalam Sulaiman, dkk, 2020) Remaja juga merupakan peserta didik dengan rentang usia 12-19 tahun, rata-rata sedang duduk dan mengenyam pendidikan setingkat SMP, SMA, dan Perguruan Tinggi. Remaja merupakan tahapan perkembangan individu antara masa anak- anak menuju masa dewasa, pada tahapan perkembangan dijelaskan bahwa remaja berada dalam masa ketegangan dan perasaan tertekan karena melalui berbagai perubahan, di antaranya adalah perubahan fisik dan motorik serta perkembangan kognitif, perkembangan sosial, dan perkembangan emosi.

Pada usia ini remaja sangat mudah terpengaruhi oleh lingkungan, danbiasanya remaja menginginkan kebebasan untuk menjalin hubungan pertemanan dengan teman sebaya. Peran teman sebaya selama perkembangan remaja sangat penting, termasuk dalam perkembangan identitas dan moral, dengan teman sebaya remaja lebih banyak mendapatkan informasi yang tidak didapatkannya di dalam keluarga, teman sebaya dapat memberikan peluang bagi remaja dalam mencari popularitas dan penerimaan (Sulaiman, dkk, 2020).

Peneriman teman sebaya merupakan bagian terpenting bagi remaja dalam segi perkembangan psikososial. Remaja yang diterima dalam sebuah hubungan pertemanan memiliki tingkat kepercayaan diri yang tinggi sehingga pencapaian di sekolah menjadi lebih baik, sebaliknya remaja yang diasingkan cenderung terlibat pada tindakan yang melanggar aturan. Agar diterima oleh teman sebaya biasanya remaja akan mengikuti aktivitas-aktivitas yang dilakukan oleh temannya (Sulaiman, dkk, 2020).

Hurlock (2013) menyebutkan bahwa penerimaan teman sebaya adalah kondisi di mana seseorang dipilih sebagai teman untuk bergabung dalam sebuah kelompok pertemanan dan melakukan aktivitas secara bersama-sama dalam kelompok tersebut, dengan melakukan hal ini anak akan memainkan perannya dalam kelompok sosial sehingga anggota kelompok lainnya menunjukkan ketertarikan untuk bekerja dan bermain bersama.

Selama pandemi Covid-19 berbagai kendala dan permasalahan dialami oleh remaja, berdasarkan survei yang dilakukan oleh Unicef tentang remaja di masa pandemi, diperoleh hasil bahwa 27\% remaja mengalami kecemasan, 15\% remaja mengalami depresi, $46 \%$ remaja tidak termotivasi untukmelakukan hal yang disenangi, dan $50 \%$ remaja membutuhkan bantuan fisik maupun psikologis, (Unicef.org, 2021).

Berkaitan dengan beberapa permasalahan yang dialami oleh remaja selama pandemi, faktor penerimaan teman sebaya juga dapat mempengaruhi. Namun kondisi selama pandemi justru membuat hubungan remaja dengan teman sebaya mengalami permasalahan. Mengutip ulasan pada situs web $d w$.com yang ditulis 
oleh Hoppner (2021) menjelaskan bahwa sebuah survei mengenai kesejahteraan dan kesehatan mental selama pandemi yang dilakukan oleh University College London menunjukkan hasil bahwa setengah dari responden menunjukkan tidak terdapat perubahan dalam hubungan persahabatan, $\quad 15 \% \quad$ menunjukkan peningkatan, dan $22 \%$ menunjukkan bahwa hubungan persahabatan dengan teman sebaya semakin memburuk.

Survei yang dilakukan di Indonesia mengenai hubungan remaja dengan teman sebaya menunjukkan hasil bahwa $51 \%$ responden mengungkapkan bahwa mereka merasa kesepian karena tidak dapat bertemu dengan teman secara langsung, $72 \%$ responden mengatakan bahwa mereka dan teman sebaya merasa tetap terhubung secara virtual, serta $51 \%$ responden setuju bahwa hubungan pertemanan mereka dengan teman sebaya memburuk dan terasa semakin jauh, (Liputan6.com, 2020).

Penelitian mengenai penerimaan teman sebaya yang dilakukan oleh Putri, dkk (2017) di Kota Padang menjelaskan bahwa penerimaan teman sebaya pada remaja kategori sedang adalah 7,8\% sebanyak 14 orang, kategori sangat tinggi adalah $25 \%$ sebanyak 45 orang, dan kategori sangat tinggi adalah $67 \%$ sebanyak 140 orang. Hal ini dapat diartikan bahwa penerimaan teman sebaya pada remaja di kota Padang tergolong dalam kategori sangat tinggi.

Masalah penerimaan teman sebaya di masa pandemi ini sangat penting untuk diperhatikan, mengingat bahwa remaja yang sedang mengalami proses perkembangan sangat membutuhkan teman dalam menjalankan tugas perkembangannya. Hal ini sejalan dengan penelitian yang dilakukan oleh Khesari (2015) bahwa penerimaan teman sebaya sangat mempengaruhi perkembangan remaja salah satunya ialah konsep diri. Dari hasil penelitiannya menunjukkan bahwa sebesar $40,4 \%$ variabel penerimaan teman sebaya dapat memberikan pengaruh terhadap konsep diri pada remaja.

Berdasarkan observasi dan wawancara singkat yang peneliti lakukan di tempat penelitian yaitu di Kabupaten Labuhanbatu Selatan terhadap remaja hasil yang ditemukan adalah: pada tanggal 22 hingga 27 Februari 2021, berdasarkan hasil observasi menunjukkan hasil bahwa remaja di masa pandemi Covid-19 terlihat lebih banyak menghabiskan waktu di rumah. Kebanyakan dari remaja menghabiskan waktu dengan mengerjakan tugas, sekolah online, bermain gadget, dan menghabiskan lebih banyak waktu bersama keluarga. Observasi yang peneliti temukan semenjak sekolah diliburkan, sosialisasi antara teman sebaya sangat berkurang, bahkan pertemuan secara daring atau melalui sosial media juga terlihat jarang sekali dilakukan, sehingga tidak menjalin komunikasi yang baik dengan teman sebaya.

Sejalan dengan hasil observasi tersebut, pada hasil wawancara yang dilakukan oleh peneliti pada tanggal 28 dan 29 Juli 2021 dengan 3 orang remaja juga didapatkan informasi tentang keadaan remaja selama pandemi, bahwa selama pandemi remaja: 1) merasakan kejenuhan, 2) merasa bosan, 3) tidak bersemangat dalam pendidikan, dan 4) sangat ingin sekali kembali pada situasi sebelum pandemi. Remaja juga mengatakan bahwa antara remaja dan teman sebaya jarang sekali menjalin komunikasi, remaja hanya menjalin komunikasi dengan beberapa teman yang tinggal dekat dengan lingkungan rumah itupun dengan tingkat usia yang tidak sama. Sedangkan dengan teman sebaya yang juga merupakan 
teman sekolah hanya beberapa kali ketika ada tugas-tugas sekolah.

Peneliti juga telah melakukan survei singkat terhadap populasi penelitian yaitu remaja di kabupaten Labuhanbatu Selatan pada tanggal 11 hingga 13 November 2021 dengan jumlah 160 remaja, hasilnya menunjukkan bahwa $80 \%$ remaja menyatakan bahwa selama masa pandemi mereka merasa terisolasi, $20 \%$ merasa dirinya tidak diterima oleh teman dan $11,3 \%$ menjawab ragu-ragu, $23,8 \%$ tidak pernah berkomunikasi dengan teman, $19,4 \%$ merasa hubungan pertemanannya semakin memburuk dan $23,8 \%$ menjawab ragu- ragu, $20 \%$ merasa dirinya tidak dipedulikan teman dan $11,3 \%$ menjawab ragu-ragu, 38,1\% menyatakan bahwa tidak ada teman yang membantu mengerjakan tugas, $28,7 \%$ menyatakan bahwa tidak ada teman yang bertanya kabar kepadanya dan $15,6 \%$ menjawab ragu-ragu, $53,8 \%$ berpendapat bahwa terbiasa mengerjakan tugas sendiri sehingga tidak membutuhkan teman dan 13,7\% menjawab ragu-ragu, serta cara remaja berinteraksi selama pandemi kebanyakan menggunakan chatting/messanger sebesar $74,4 \%$.

Berdasarkan hasil observasi, wawancara, dan survei yang telah peneliti lakukan, maka dapat diketahui bahwa selama masa pandemi Covid-19 terdapat remaja yang merasakan bahwa hubungan pertemanannya dengan teman sebaya semakin memburuk, terdapat remaja yang tidak diperdulikan oleh teman sebaya, dan terdapat juga remaja yang tidak mendapatkan bantuan dari teman saat mengerjakan tugas, dan remaja merasa dirinya tidak diterima oleh teman sebaya.

Penelitian Izzaty (2011) tentang penerimaan teman sebaya menjelaskan bahwa cara remaja dalam mengartikan dan merespon situasi sosialnya menunjukkan cara berinteraksi serta status penerimaan sosial oleh teman sebayanya, adanya penerimaan dan penolakan dari teman sebaya sangat penting untuk diperhatikan sehingga tahapan perkembangan remaja berikutnya akan menjadi lebih baik, di mana interaksi antar teman sebaya akan memotivasi dan mendukung kemampuan sosial yang kritis, meningkatkanpemahaman hubungan antar individu, dan mengetahui perasaan yang dapat diterima secara sosial. Menurut Parker (dalam Dayakisni \& Hunaidah, 2015) beberapa aspek-aspek dalam penerimaan teman sebaya adalah sebagai berikut: pengakuan dan kepedulian, kebersamaan, saling membantu, dan keakraban.

Kurangnya interaksi sosial dapat menghambat terjadinya penerimaan teman sebaya pada remaja, yang sebaliknya terjadi adalah adanya penolakan. Hal ini sejalan dengan penelitian Sutarjo (2015) tetang hubungan interaksi sosial dengan penerimaan teman sebaya, hasilnya menunjukkan bahwa $45,6 \%$ variabel interaksi sosial dapat mempengaruhi penerimaan teman sebaya pada remaja.

Melka, dkk (2018) menyebutkan bahwa salah satu faktor yang sangat memiliki peran penting dalam penerimaan atau penolakan dari teman sebaya adalah kecerdasan emosi. Terkait hal ini sesuai dengan pendapat Damayanti dan Haryanto (2017) yang mengatakan bahwa ketika seseorang menghadapi konflik dalam pertemanan kelompok sebaya salah satu yang sangat dibutuhkan adalah kecerdasan emosi, sehingga kecerdasan emosi pada remaja sangat perlu untuk diasah dan dikembangkan, selain itu dalam menjalin hubungan pertemanan antar teman sebaya dibutuhkan pula pemahaman akan diri sendiri maupun orang lain, remaja harus bisa menyadari dan menghormati perbedaan antar individu, baik tentang kepribadian, 
perspektif, kebutuhan, dan hal-hal kecil lainnya.

Kecerdasan emosi adalah sebuah kemampuan yang digunakan untuk dapat mengenali perasaan diri sendiri dan orang lain, selain itu kecerdasan emosi juga dapat memotivasi dan mengelola emosi sendiri dengan baik, serta kecerdasan emosi dapat menjadikan hubungan individu dengan orang lain menjadi lebih baik (Goleman dalam Melka, dkk 2018).

Kecerdasan emosi merupakan kemampuan dalam mengindera, memahami dalam kekuatan yang dimiliki, ketajaman, menjadikan emosi sebagai kebutuhan, informasi, dan pengaruh (Cooper \& Sawaf dalam Wiyono, 2019).

Santrock (2017) mengatakan bahwa yang berperan penting dalam hubungan teman sebaya bukan hanya kognisi melainkan emosi. Dengan emosiyang lebih baik yang dimiliki oleh tiap remaja maka dalam hubungan pertemanan, remaja akan cenderung lebih bisa menerima keadaan dan kondisi temannya. Saling mendukung dan bisa sama-sama belajar dalam sistem yang sama untuk mewujudkan harapan, keinginan, dan cita-cita yang dimiliki. Goleman (2015) menyebutkan aspek kecerdasan emosi ada lima wilayah, di antanya adalah sebagai berikut: mengenali emosi diri, mengelola emosi, memotivasi diri sendiri, menenali emosi orang lain, dan membina hubungan.

Berdasarkan uraian permasalahan di atas, adapun rumusan masalah dalam penelitian ini adalah "Apakah ada Hubungan antara Kecerdasan Emosi dengan Penerimaan Teman Sebaya pada Remaja di masa Pandemi Covid-19?. Tujuan penelitian ini untuk mengetahui Hubungan antara Kecerdasan Emosi dengan Penerimaan Teman Sebaya pada Remaja di masa Pandemi Covid-19.

\section{METODE PENELITIAN}

Populasi dalam penelitian adalah semua remaja usia 12-19 tahun di kabupaten Labuhanbatu Selatan yang berjumlah 45.216 orang. Sampel yang digunakan untuk penelitian adalah sebanyak 100 orang yang dihitung dengan menggunakan rumus Slovin dengan tingkat kesalahan pengambilan sampel sebesar $10 \%$, adapun teknik sampel yang digunakan adalah Accidental Sampling, yaitu teknik pengambilan sampel secara kebetulan sesuai dengan karakteristik sampel yang sesuai sehingga dapat dijadikan sumber data penelitian (Sugiyono, 2017). Metode pengumpulan data yang digunakan adalah skala dan penelitian ini termasuk dalam penelitian kuantitatif dengan metode analisis korelasi Spearman's Rank.

\section{HASIL DAN PEMBAHASAN}

Tabel 1

Hasil Uji Normalitas

\begin{tabular}{lll}
\hline Variabel & Sig & Ket \\
\hline Penerimaan & 0,021 & Tidak \\
Teman & $(<$ & Normal \\
Sebaya & $0,05)$ & \\
Kecerdasan & 0,054 & Normal \\
Emosi & $(>$ & \\
& $0,05)$ & \\
\hline
\end{tabular}

Berdasarkan pada tabel hasil uji normalitas di atas, maka dapat diketahui bahwa nilai signifikansi variabel penerimaanteman sebaya adalah 0,021 (p $<0,05$ ) sehingga data dikatakan tidak normal, sedangkan nilai signifikansi pada variabel kecerdasan emosi adalah 0,054 ( $p$ $>0,05)$ dan data dikatakan normal. Karena data berdistribusi tidak normal, maka uji statistik yang digunakan adalah non parametrik. 
Tabel 2

Hasil Uji Linieritas

\begin{tabular}{lccc}
\hline \multicolumn{1}{c}{ Variabel } & F & Sig & Ket \\
\hline Penerimaan & 58, & 0,000 & Linier \\
Teman & 137 & & \\
Sebaya & & & \\
Kecerdasan & & & \\
Emosi & & & \\
\hline
\end{tabular}

Berdasarkan data pada tabel hasil uji linieritas di atas, maka dapat diketahui bahwa nilai $F$ linearity adalah 0,000 (< $0,05)$, sehingga dapat disimpulkan bahwa variabel $(Y)$ yaitu penerimaan teman sebaya dengan variabel $(X)$ yaitu kecerdasan emosi memiliki hubungan yang linier.

Tabel 3

Hasil Uji Hipotesis

\begin{tabular}{lcll}
\hline \multicolumn{1}{c}{ Variabel } & (r) & Sig & \multicolumn{1}{c}{ Ket } \\
\hline Penerimaan & 0,547 & 0,00 & Signifikan \\
Teman & & 0 & \\
Sebaya & & & \\
Kecerdasan & & & \\
Emosi & & & \\
\hline
\end{tabular}

Berdasarkan analisis korelasi spearman rho yang ditunjukan pada tabel di atas, dapat diketahui bahwa nilai signifikansi sebesar $0,000(<0,05)$ sehingga antara variabel $(Y)$ yakni penerimaan teman sebaya dan variabel $(X)$ yakni kecerdasan emosi adalah berkolerasi. Untuk nilai koefisien korelasi adalah sebesar 0,547 sehingga derajad hubungan antara kedua variabel berada pada korelasi sedang, maka hipotesis pada penelitian ini dapat diterima. Kesimpulan ini dirujuk berdasarkan hasil analisis data menggunakan uji korelasi spearman rho, di mana nilai signifikansi adalah sebesar
0,000 , yang mana nilai ini $<0,05$ sehingga antara variabel $(\mathrm{X})$ dan variabel $(\mathrm{Y})$ dalam penelitian ini berkorelasi. Sedangkan nilai korelasi penelitian ini adalah sebesar 0,547 , yang berarti korelasi adalah positif, di mana semakin tinggi tingkat kecerdasan emosi maka semakin tinggi tingkat penerimaan teman sebaya pada remaja.

Menurut Melka, dkk (2018) salah satu faktor yang berperan penting dalam penerimaan teman sebaya ialah kecerdasan emosi, hasil penelitiannya yang berjudul hubungan antara kecerdasan emosi dengan penerimaan teman sebaya serta implikasinya dalam bimbingan dan konseling menunjukkan hasil yang signifikan dengan nilai signifikansi sebesar 0,000 dan nilai koefisien korelasi sebesar 0,054. Hal ini menunjukkan bahwa terdapat hubungan yang signifikan antara kecerdasan emosi dengan penerimaan teman sebaya. Artinya semakin tinggi kecerdasan emosi maka semakin tinggi penerimaan teman sebaya, sebaliknya semakin rendah kecerdasan emosi maka semakin rendah penerimaan teman sebaya.

Hurlock (2013) menyebutkan bahwa yang termasuk ciri penerimaan teman sebaya adalah kematangan sosial dan emosi, dengan kematangan sosial dan emosi yang baik remaja mampu menilai dan dapat menyesuaikan diri dengan cepat terhadap orang lain, serta cerdas dalam bersikap dan tidak berlebihan. Hal ini menunjukkan bahwa kematangan emosi berkaitan dengan kecerdasan emosi apabila menunjukkan arah yang baik maka akan dapat mempengaruhi penerimaan teman sebaya.

Berdasar pada penelitian yang telah dilakukan adapun besarnya pengaruh yang diberikan oleh kecerdasan emosi terhadap penerimaan teman sebayadapat dilihat dari nilai $R$ square sebesar 0,351. Hal ini menyatakan bahwa kontribusi variabel 
kecerdasan emosi memberikan pengaruh sebesar $35,1 \%$ terhadap penerimaan teman sebaya, sehingga $64,9 \%$ sisanya penerimaan teman sebaya dapat dipengaruhi oleh faktor-faktor yang lain yang tidak dibahas dalam penelitian ini.

Pada penelitian sebelumnya yang dilakukan oleh Wardani (2012) juga menunjukkan bahwa terdapat hubungan yang positif dan signifikan antara kecerdasan emosi dengan penerimaan teman sebaya pada siswa akselerasi di SMAN 8 Pekanbaru, dengan nilai ( $r x y=$ 0,609 dengan $p=0,000<0,05$ ). Penelitian yang dilakukan oleh Steven dan Howard (dalam Goleman, 2015) mengungkapkan bahwa semakin tinggi tingkat kecerdasan emosi pada seseorang maka akan semakin positif penerimaan teman sebaya yang dilihat dari kemampuan merasakan dan mengelola perasaan orang lain dengan baik, sebaliknya jika semakin rendah kecerdasan emosi maka semakin negatif penerimaan teman sebaya yang dilihat dari kesulitan bersosialisasi dan bekerjasama.

Pada penelitian Damayanti dan Haryanto (2017) yang berjudul kecerdasan emosional dan kualitas hubungan persahabatan diperoleh hasil penelitian yang positif dan signifikan antara kecerdasan emosional dengan kualitas hubungan persahabatan dengan koefisien korelasi sebesar 0,532 dan nilai signifikansi sebesar 0,000. Dalam penelitian ini juga disebutkan bahwa ketika seseorang menghadapi konflik dalam pertemanan kelompok sebaya salah satu yang sangat dibutuhkan adalah kecerdasan emosi, sehingga kecerdasan emosi pada remaja sangat perlu untuk diasah dan dikembangkan, selain itu dalam menjalin hubungan pertemanan antar teman sebaya dibutuhkan pula pemahaman akan diri sendiri maupun orang lain, remaja harus bisa menyadari dan menghormati perbedaan antar individu, baik tentang kepribadian, perspektif, kebutuhan, dan hal-hal kecil lainnya.

Kecerdasan emosi adalah hal yang sangat penting dalam membentuk kepribadian di dalam diri, salah satu cara untuk dapat mengembangkan kecerdasan emosi adalah dengan interaksi teman sebaya (Hanifa \& Lestari, 2021). Di masa pandemi Covid-19, remaja mengalami banyak sekalipermasalahan, salah satunya adalah terbatasnya ruang gerak sehingga sulit untuk bersosialisai dengan teman sebaya. Terkait dengan situasi ini kecerdasan emosi menjadi perhatian bagi remaja untuk terus dapat dikembangkan meski dalam situasi pandemi. Karena dengan kecerdasan emosi yang baik, maka akan memberikan dampak yang baik terhadap penerimaan teman sebaya pada remaja. Hal ini sejalan dengan penelitian terdahulu yang dilakukan oleh Ammar (2014) di mana terdapat hubungan yang signifikan antara interaksi teman sebaya dengan kecerdasan emosi dengan nilai signifikansi 0,000 dan nilai korelasi sebesar 0,872 .

Salah satu kasus yang menjelaskan permasalahan remaja di masa pandemi Covid-19 yang telah penulis jelaskan pada latar belakang masalah menjelaskan bahwa prestasi remaja juga menjadi suatu tantangan yang sulit untuk dicapai di masa pandemi, hal ini karena kurangnya dukungan dan penerimaan teman sebaya. Menurut (Sulaiman, dkk, 2020) teman sebaya adalah sesuatu yang penting bagi remaja untuk meraih pencapaian yang diinginkan oleh remaja termasuk di sekolah. Penelitian lainnya yang sejalan dengan pembahasan ini dilakukan oleh Sumiati dan Chairunnissa (2010) yang menjelaskan bahwa terdapat hubungan yang signifikan antara penerimaan teman sebaya dengan prestasi akademik pada 
mahasiswa, dengan nilai korelasi sebesar 0,494 , di mana semakin tinggi penerimaan teman sebaya maka semakin tinggi prestasi akademik.

Penelitian ini tentunya terdapat kelebihan dan kelemahan dari berbagai aspek, sehingga kritik, saran, dan masukan sangat dibutuhkan untuk memperbaiki penelitian ini sehingga menjadi lebih baik lagi. Adapun kelemahan dalam penelitian ini adalah teknik pengambilan sampel menggunakan jenis non-probability sampling sehingga data yang diperoleh tidak berdistribusi normal, adapun kelemahan lainnya adalah keterbatasan dalam penyebaran kuesioner dan jumlah responden yang masih terbilang sedikit, penulis tidak dapat melihat langsung saat responden melakukan pengisian kuesioner sehingga mungkin terdapat jawaban yang tidak sesuai, dan juga terdapat beberapa aitem yang mungkin sulit untuk dimengerti dan dipahami oleh responden.

\section{SIMPULAN}

Berdasarkan penelitian yang telah dilakukan, maka dapat ditarik kesimpulan bahwa terdapat hubungan yang signifikan antara kecerdasan emosi dengan penerimaan teman sebaya pada remaja di masa pandemi Covid-19. Adapun arah yang ditunjukkan pada penelitian ini yaitu kecerdasan emosi memiliki arah yang positif terhadap penerimaan temansebaya, artinya semakin tinggi tingkat kecerdasan emosi maka semakin tinggi tingkat penerimaan teman sebaya, sebaliknya jika tingkat kecerdasan emosi rendah maka semakin rendah pula tingkat penerimaan teman sebaya.

\section{DAFTAR PUSTAKA}

Ammar, A.M. (2014). Hubungan Antara Interaksi Teman Sebaya Dengan Kecerdasan Emosional Siswa Kelas V
SD N 1 Bedagas Kecamatan Pengadegan Purbalingga. Skripsi. Fakultas IImu Pendidikan Universitas Negeri Yogyakarta.

Asrori, A., Hidayat, T., \& Nugroho, A.A. (2010). Hubungan Kecerdasan Emosi Dan Interaksi Teman Sebaya Dengan Penyesuaian Sosial Pada Siswa Kelas VIII Program Akselerasi Di SMP Negeri 9 Surakarta. Jurnal Wacana, 2(1), 1-25.

Azwar, S. (2012). Reliabilitas Dan Validitas. Yogyakarta: Pustaka Belajar. Azwar, S. (2017). Penyusunan Skala Psikologi. Yogyakarta: Pustaka Belajar. Bagia, I.W. (2015). Perilaku Organisasi. Yogyakarta: Graha IImu.

Badan Pusat Statistik. (2021). Kabupaten Labuhanbatu Selatan Dalam Angka. Diunduh pada 1 November 2021 dari https://labuhanbatuselatankab.bps.go.i/.

Bungin, B. (2017). Metodologi Penelitian Kuantitatif: Komunikasi, Ekonomi, Dan Kebijakan Publik Serta IImu-IImu Sosial Lainnya. Jakarta: Kencana Prenada.

Carr, A. (2011). Positive Psychology The Science Of Happiness And Human Strengths. New York: BrunnerRoutledge.

Chusniyah, T. (2015). Problem Dalam Psikologi Perkembangan Anak Yang Berhadapan Dengan Hukum. Artikel. Diunduh pada 1 November 2021 dari http://fppsi.um.ac.id/problem-dalamperkembangan-psikologi-anak-yangberhadapan-dengan-hukum-abh/.

Damayanti, P., \& Haryanto. (2017). Kecerdasan Emosional Dan Kualitas Hubungan Persahabatan. Gadjah Mada Journal Of Psychology, 3(2), 86- 97.

Dayakisni, T., \& Hunaidah. (2015). Psikologi Sosial. Malang: UMM Press.

Gariba, A., \& Awini, A. (2021). Peer Acceptance And Perception Of Acceptance Of Students With Visual Impairments In An Inclusive Setting In Ghana. European Journal Of Special Education Research, 7(4), 1-25.

Goleman, D. (2015). Emotional Intellegence Kecerdasan Emosional Mengapa El Lebih Penting Daripada IQ. Jakarta: Gramedia. 
Hanifa, S., \& Lestari, T. (2021). Pengaruh Teman Sebaya Terhadap Perkembangan Emosional Anak. Jurnal Pendidikan Tambusai, 5(1), 1429- 1433.

Hoppner, S. (2021). Bagaimana Pandemi Corona Mempengaruhi Persahabatan?. Retrieved August 2, 2021 from https://www.dw.com/id/bagaimanapandemi-corona-memengaruhipersahabatan/a-56624150.

Hurlock, E.B. (2012). Perkembangan Anak Jilid 2 Edisi Keenam. Jakarta: Erlangga.

Hurlock, E.B. (2013). Perkembangan Anak Jilid 1 Edisi Keenam. Jakarta: Erlangga.

Izzaty, R.E. (2011). Penerimaan Teman Sebaya Sebagai Indikator Kemampuan Penyesuaian Diri: Arti Penting Pengembangan Karakter Sejak Usia Dini. Skripsi. Fakultas IImu Pendidikan Universitas Negeri Yogyakarta.

Judika, E.R.S., Sutatminingsih, R., \& Yusuf, E.A. (2021). The Relationship Between Peer Acceptance And Online Game Addiction In Adolescents. International Journal Of Sciences And High Technologies, 24(2), 290-293.

Khesari, N. (2015). Hubugan Antara Penerimaan Kelompok Teman Sebaya Dengan Konsep Diri Pada Remaja. Naskah Publikasi. Fakultas Psikologi Universitas Muhammadiyah Surakarta.

Kompas.com. (2021). Cerita Lia Hampir Setahun Belajar Jarak Jauh Karena Pandemi Mengaku Sedih, Kesepian, dan Putus Asa. Surat Kabar. Diunduh pada 2 Agustus, 2021 dari

https://regional.kompas.com/read/2021/ 02/19/06560031/cerita-lia-hampirsetahun-belajar-jarak-jauh-karenapandemi-mengaku-sedih?page=all.

Lee, L., William, A., Lao, C., Lagunas, N., \& Langner, C.A. (2021). The Role Of Home Language In Children's Friendship Choice And Peer Acceptance. Journal Of Applied Developmental Psychology, 76, 1-11.

Liputan6.com. (2020). Survei Snapchat Ungkap Pandemi Covid-19 Pengaruhi pertemanan. Artikel. Diunduh pada $10 \quad$ November 2021 dari https://www.liputan6.com/cekfakta/read/4404395/survei-snapchat- ungkap-pandemi-covid-19-pengaruhipertemanan.

Melka, F.D., Ahmad, R., Firman., Syukur, Y., Sukmawati, I., \& Handayani, P.G. (2018). Hubungan Kecerdasan Emosional Dengan Penerimaan Teman Sebaya Serta Implikasinya Dalam Bimbingan Dan Konseling. Jurnal Neo Konseling, 00(00), 1-7.

Prakoso, M.R.N., \& Farozin, M. (2019). Contribution Of Emotional Intelligence To Peer Acceptance On Students At Public Junior High School 14 Surakarta. Journal Advances In Social Science, Education, And Humanities Research, 46(2), 1-25.

Putri, S.H. (2016). Pengaruh Kecerdasan Emosi Dan Kecerdasan Spiritual Dengan Kecenderungan Berperilaku Delinkuen Pada Remaja. Skripsi. Fakultas Psikologi Universitas Islam Riau.

Putri, S.R., Syahniar., \& Alizamar. (2017). Kontribusi Tingkat Penerimaan Oleh Teman Sebaya Dan Konsep Diri Terhadap Motivasi Belajar Peserta Didik Di SMK Nusatama Padang Serta Implikasinya Dalam Program Bimbingan Dan Konseling. Jurnal Bimbingan Dan Konseling, 6(4), 223-234.

Rahmana, A. (2012). Hubungan Penerimaan Teman Sebaya Terhadap Tingkat Kepercayaan Diri Remaja. Skripsi. Fakultas Psikologi Universitas Islam Riau.

Santrock, J.W. (2017). Psikologi Pendidikan Edisi Kedua. Jakarta: Kencana.

Sarwono, J. (2018). Metode Penelitian Kuantitatif Dan Kualitatif Edisi 2. Yogyakarta: Suluh Media.

Setiaji, C.A. (2018). Pertumbuhan Dan Perkembangan Peserta Didik Dan Anak Berkebutuhan Khusus. Yogyakarta: Media Akademi.

Siregar, S. (2012). Metode Penelitian Kuantitatif Dilengkapi Dengan Perbandingan Perhitungan Manual \& SPSS. Jakarta: Kencana Prenada.

Sugiyono. (2017). Metode Penelitian Kuantitatif Kualitatif Dan R\&D. Bandung: Alfabeta. 
Sulaiman, H., Purnama, S., Holilullah, A., Hidayati, L., \& Saleh, N.H. (2020). Psikologi Perkembangan Anak Dan Remaja Pengasuhan Anak Lintas Budaya. Bandung: Remaja Rosdakarya.

Sumiati, A., \& Chairunnissa. (2010). Hubungan Antara Penerimaan Kelompok Teman Sebaya Dengan Prestasi Akademik Mahasiswa Pada Fakultas Ekonomi Universitas Negeri Jakarta. Jurnal Ekonomi \& Pendidikan, 8(2), 105-118.

Sutarjo, D.A.P. (2015). Hubungan Antara Interaksi Teman Sebaya Dengan Penerimaan Sosial Pada Siswa Kelas $X$ Di SMA N 9 Yogyakarta. Skripsi. Fakultas IImu Pendidikan Universitas Negeri Yogyakarta.

Suwatra, I.W. (2014). Sosiologi Pendidikan. Yogyakarta: Graha Ilmu.

Triani, A. (2012). Pengaruh Persepsi Penerimaan Teman Sebaya Terhadap Kesepian Pada Remaja. Jurnal
Penelitian Dan Pengukuran Psikologi, 1(1), 128-134.

Tridhonanto, Al., \& Agency, B. (2010). Meraih Sukses Dengan Kecerdasan Emosional. Jakarta: Kompas Gramedia.

Unicef.org. (2021). Tetap Berprestasi Di Tengah Pandemi Covid-19. Artikel. Diunduh pada 1 November 2021 dari

https://www.unicef.org/indonesia/id/coro navirus/cerita/tetap-berprestasi- ditengah-pandemi-covid-19.

Wardani, F.E. (2012). Hubungan Antara Kecerdasan Emosional Dengan Penerimaan Teman Sebaya Pada Siswa Akselerasi SMA N 8 Pekanbaru. Skripsi. Fakultas Psikologi Universitas Islam Negeri Sultan Syarief Kasim Riau. Wiyono, K.S. (2019). Berpikir Dengan IQ, $E Q$, Dan SQ. Banten: Loka Aksara.

Yusuf, M. (2014). Metode Penelitian Kuantitatif, Kualitatif, \& Penelitian Gabungan. Jakarta: Prendamedia Group. 